\title{
The main character's personality in the trilogy novel of Negeri 5 Menara, Ranah 3 Warna, dan Rantau 1 Muara written by Ahmad Fuadi: literature study of SMA
}

\author{
Ratna Dewi Kartikasari, \\ Universitas Muhammadiyah Jakarta \\ Lasmi Hartati*), \\ Universitas Muhammadiyah Jakarta \\ *) Correspondences author: Ciputat, Jl. K.H. Ahmad Dahlan, Cireundeu, Ciputat Tim., Tangerang, Banten 15419, Indonesia; \\ e-mail: lasmihartati24@gmail.com
}

\begin{abstract}
This research is motivated by the interest of researcherto find out how the personality of the main characterscontained in the trilogy of novel Negeri 5 Menara, Ranah 3 Warna, Rantau 1 Muara by Ahmad Fuadi with literature psychology study. This research uses descriptive qualitative method used to describe personality of main charactertrilogy in these novels. The results showed that the personality of the main character in the trilogy novel as many as 18 personalities.In the novelNegeri5 Menara as many as 5 personalitieswith two personalitiestypeconsist ofphlegmatis (tough, consistent, diligence, empathy) and type choleris(courage). In the novel Ranah 3 Warna as many as 7 personalitieswith two personalitiestype gepasioner(hardworker, strong, confident)and type phlegmatis(intelligent, simple, caring,tough). While, in the novel Rantau 1 Muara as many as 6 personalitieswith three personalities type consist ofphlegmatis(diligent, consistent, care, tough),gepasioner(hard worker) and choleris(courage).Thus, it can be concluded that tough personality is more dominant because the personality is presented in the trilogy novel. It indicates that the main characters havetough personality in studying especially reaching for dreams. This research is implemented in SMAN 11 Kota Tangerang Selatan and it can be concluded that the student understand in analyzing the personality of the main character in the trilogy novel by Ahmad Fuadi.
\end{abstract}

Key Words: Trilogy Novel, PersonalityFigure, Literary Psychology.

Article History: Received: 29/10/2018; Revised: 27/11/2018; Accepted: 15/12/2018; Published: 25/12/2018

How to Cite (MLA $\left.7^{\text {th }}\right)$ Kartikasari, Ratna Dewi and Lasmi Hartati. "The main character's personality in the trilogy novel of Negeri 5 Menara, Ranah 3 Warna, dan Rantau 1 Muara written by Ahmad Fuadi: literature study of SMA." Hortatori Jurnal Pendidikan Bahasa dan Sastra Indonesia 2.2 (2018): 109-119. Print/Online. Copyrights Holder: Kartikasari, Ratna Dewi and Lasmi Hartati. First Publication: Hortatori Jurnal Pendidikan Bahasa dan Sastra Indonesia (2018).

This work is licensed under a Creative Commons Attribution-ShareAlike 4.0 International License.

\section{Pendahuluan}

Novel merupakan karya fiksi yang dapat diangkat dari kehidupan seseorang. Jassin dalam Purba menyatakan bahwa adalah cerita mengenai salah satu episode dalam kehidupan manusia, suatu kejadian yang luar biasa dalam kehidupan itu, sebuah krisis yang memungkinkan terjadinya perubahan nasib pada manusia. Dalam novel selalu ada tokoh dan penokohan. Tokoh adalah orang yang berperan dalam sebuah karya sastra dan sebagai unsur pembangun dalam sebuah cerita. Seorang pengarang juga pasti menggambarkan bagaimana kepribadian tokoh yang terdapat dalam cerita tersebut. Djaali (2009: 3) menyatakan bahwa kepribadian merupakan gabungan dari berbagai sifat dan konsep diri orang.

Tokoh dalam novel adalah bagian terpenting dalam sebuah cerita, begitu juga dalam trilogi novel Negeri 5 Menara, Ranah 3 Warna, dan Rantau 1 Muara karya Ahmad Fuadi. Menurut Sudjiman dalam 
110 The main character's personality in the trilogy novel of Negeri 5 Menara, Ranah 3 Warna, dan Rantau 1 Muara written by Ahmad Fuadi: literature study of SMA

Rokhmansyah (2014: 34) tokoh adalah individu rekaan yangmengalami peristiwa atau berlaku andil dalam berbagai peristiwa cerita. Penokohan adalah pelukisan gambaran yang jelas tentang seseorang yang ditampilkan dalam sebuah cerita (Jones dalam Nurgiyantoro, 2013: 247).

Penelitian ini membahas tentang kepribadian tokoh utama dalam trilogi novel. Kepribadian tokoh utama dalam trilogi novel tersebut yang sangat luar biasa, seperti kegigihan, pekerja keras, pantang menyerah, dan kesabaran tokoh utama dalam menghadapi berbagai macam rintangan yang harus dihadapi dalam hidupnya, khususnya dalam menuntut ilmu. Cerita dalam novel tersebut sangat menginspirasi, sehingga peneliti sangat tertarik untuk menganalisis kepribadian tokoh utama dalam trilogi novel Negeri 5 Menara, Ranah 3 Warna, Rantau 1 Muara karya Ahmad Fuadi dengan kajian psikologi sastra. Ratna, (2015: 342) menyatakan bahwa secara definitif, tujuan psikologi sastra adalah memahami aspek-aspek kejiwaan yang terkandung dalam suatu karya sastra.

\section{Metode}

Penelitian dengan metode deskriptif kualitatif pada kajian psikologi sastra dalam novel merupakan upaya untuk meneliti dan mendeskripsikan kepribadian-kepribadian tokoh utama dalam trilogi novel. Teknik pengumpulan data dalam penelitian ini dilakukan beberapa tahap berikut. Pertama, membaca dengan teliti trilogi novel karya Ahmad Fuadi. Kedua, melakukan proses identifikasi kepribadian tokoh utama dalam trilogi novel karya Ahmad Fuadi. Ketiga, melakukan klasifikasi data kepribadian tokoh utama dalam trilogi novel karya Ahmad Fuadi berdasarkan tipe-tipe kepribadian. Keempat, mengadakan studi kepustakaan tentang kepribadian tokoh utama dalam trilogi novel karya Ahmad Fuadi.Dalam penelitian ini, teknik analisis data yang digunakan adalah analisis data interaktif. Hubberman dan Milles dalam Fuad dan Nugroho (2014: 63) menyatakan bahwa terdapat tiga hal dalam analisis interaktif, yakni reduksi data, penyajian data, dan penarikan kesimpulan atau verifikasi sebagai sesuatu yang jalin-menjalin pada saat sebelum, selama, dan sesudah pengumpulan data dalam bentuk yang sejajar.

\section{Hasil dan Diskusi}

Heymans dalam Suryabrata, (2011: 70) membagi tipe kepribadian manusia berdasarkan kualitas kejiwaan, yakni emosionalitas, proses pengiring, dan aktivitas. Namun berdasarkan ketiga unsur tersebut dalam diri setiap orang digolongkan menjadi delapan tipe kepribadian yakni: Gepasioner (orang hebat), sentimentil (orang perayu), choleris (pemberani), nerveus (orang penggugup), phlegmatis (orang tenang), apathis, sanguinis (orang kekanak-kanakan), amorph (orang tak berbentuk). Berdasarkan kedelapan tipe kepribadian di atas setiap individu memiliki satu tipe kepribadian. Satu tipe kepribadian ini, akan menunjukkan sikap atau perilaku seseorang yang beragam (Heymans, 2011: 71-72).

\section{Analisis Kepribadian Alif dalam Novel Negeri 5 Menara Karya Ahmad Fuadi}

Aspek kepribadian tokoh utama dalam novel Negeri 5 Menara karya Ahmad Fuadi kajian psikologi sastra meliputi kepribadian tipe phlegmatis dan choleris.

a. Tipe phlegmatis

Tipe phlegmatis disebut juga dengan tipe orang tenang. Menurut Heymans dalam Suryabrata (2011: 70), tipe ini memiliki kriteria sifat diantaranya adalah tidak lekas putus asa, dan tenang. Dalam analisis novel Negeri 5 Menara karya Ahmad Fuadi, Alif (tokoh utama) memiliki 5 kepribadian seperti pantang menyerah, tawakal, tekun, dan empati dengan sifat yang berbeda-beda.

1. Pantang menyerah

Menurut teori kepribadian Heymans kepribadian “pantang menyerah” masuk masuk ke dalam kualitas kejiwaan proses pengiring. Proses pengiring merupakan banyak sedikitnya pengaruh kesan-kesan terhadap kesadaran. Kepribadian pantang menyerah berarti kepribadian yang sifatnya tidak lekas putus asa. Oleh karena itu, kepribadian ini termasuk tipe kepribadian phlegmatis. Dalam novel ini, kepribadian Alif yang pantang menyerah adalah seperti pada kutipan berikut. 
"Aku berdiri sambil mengulet untuk mengusir kantuk. Setelah membasahi muka dan mengambil whudu, kantukku lumayan reda. Setiap aku merasa harus menyerah dan tidur, aku melecut diriku, "ayo satu halaman lagi, satu baris lagi, satu kata lagi..." Akhirnya dengan perjuangan, aku bisa menamatkan bacaanku. Dengan lega aku angkat buku itu dan benamkan di wajahku sambil berdoa, "Ya Allah telah aku sempurnakan semua usahaku dan doaku kepadaMu” (Fuadi, 2013: 199).

Kutipan di atas menggambarkan kepribadian Alif yang pantang menyerah ketika harus menghadapi ujian lisan dan tertulis nanti. Ujian yang sangat berbeda dengan ujian yang sudah ditempuh selama ini, membuat Alif semakin terbebani, karena begitu banyak pelajaran yang harus dipelajari untuk menghadapi ujian lisan dan tertulis nanti. Selain itu yang membuatnya terbebani adalah semua soal ujian tidak menggunakan bahasa Indonesia. Karena kelemahan Alif adalah menghapal dan pelajaran bahasa Arab.

2. Tawakal

Menurut teori kepribadian Heymans kepribadian "tawakal" masuk ke dalam sifat yang tenang yang proses pengiringnya kuat. Proses pengiring merupakan banyak sedikitnya pengaruh kesan-kesan terhadap kesadaran. Kepribadian tawakal berarti kepribadian yang sifatnya tenang. Oleh karena itu, kepribadian ini termasuk tipe kepribadian phlegmatis. Dalam novel ini, kepribadian Alif yang tawakal adalah seperti pada kutipan berikut.

"Yang jelas hatiku puas dan tentram karena merasa telah melakukan yang terbaik, berusaha berbuat di atas rata-rata orang dan telah berdoa dan bertawakal. Hanya kepada Allah yang Maha Mengatur segala hal" (Fuadi, 2013: 391).

Kutipan di atas menggambarkan kepribadian Alif yang selalu tawakal atas apa yang sudah dilakukan. Alif yang pada saat itu sedang berjuang untuk menaklukkan semua ujian yang akan dihadapi nanti. Ujian penentuan kelulusan, tentu membuat Alif semakin giat dalam belajar. Segala usaha akan dilakukan untuk mendapatkan hasil yang terbaik. Setelah selesai melaksanakan ujian tulis, tentu hari itu merupakan hari pembebasan dan kemerdakaan bagi semua siswa PM. Karena merasa telah melunasi hutang besar dengan tunai. Alif pun merasa puas dan tenang karena telah melakukan yang terbaik dan sesuai dengan kemampuannya. Tidak lupa juga berdoa dan tawakal kepada Allah untuk hasil ujiannya.

3. Tekun

Menurut teori kepribadian Heymans kepribadian "tekun" masuk ke dalam sifat tenang yang proses pengiringnya kuat. Proses pengiring merupakan banyak sedikitnya pengaruh kesankesan terhadap kesadaran. Kepribadian tekun berarti kepribadian yang sifatnya tenang. Oleh karena itu, kepribadian ini termasuk tipe kepribadian phlegmatis. Dalam novel ini, kepribadian Alif yang tekun adalah seperti pada kutipan berikut.

"Alhamdulillah, selesai tahajud badanku terasa lebih enteng dan segar. Aku siap sahurul lail, belajar keras dini hari sampai subuh. Dengan setumpuk buku di tangan, sarung melilit di leher dan sebuah sajadah, aku bergabung dengan para pelajar malam lainnya di teras asrama" (Fuadi, 2013: 197).

Kutipan di atas menggambarkan kepribadian Alif yang sangat tekun dalam belajar. Setelah selesai salat Tahajud, dengan tekun Alif mulai membaca semua buku pelajaran yang akan diujiankan nanti. Ada setumpuk buku yang harus dipelajari dalam beberapa malam terakhir untuk belajar bahkan menghapal pelajaran yang belum dipahami. Alif belajar bersama temanteman yang lain di teras asrama.

4. Empati

Menurut teori kepribadian Heymans kepribadian "empati” masuk ke dalam sifat tenang yang proses pengiringnya kuat. Proses pengiring merupakan banyak sedikitnya pengaruh kesankesan terhadap kesadaran. Kepribadian empati berarti kepribadian yang sifatnya tenang. Oleh karena itu, kepribadian ini termasuk tipe kepribadian phlegmatis. Dalam novel ini, kepribadian Alif yang tekun adalah seperti pada kutipan berikut.

"Kami mendekat dan merangkul bahunya. Dalam hati aku berjanji akan membantunya sekuat mungkin. Baso mengangguk-angguk berterima kasih sambil meniup-niup hidungnya 
yang tersumbat duka. Tiba-tiba hidungku juga ikut berair seperti orang pilek" (Fuadi, 2013: 363).

Kutipan di atas merupakan kepribadian Alif yang sangat empati kepada Baso ketika mendengar semua cerita tentang keluarganya. Baso mempunyai mimpi untuk bisa menghapal Alquran $30 \mathrm{Juz}$ dan bisa melanjutkan study-nya ke luar negeri yaitu Mekkah dan Madinah. Baso berjanji untuk segera menghapal semua Juz agar bisa membantu kedua orang tuanya di akhirat. Hal itu juga yang membuat Alif sangat empati kepada Baso. Alif bahkan masih sangat bersyukur karena masih memiliki orang tua, meskipun terkadang kiriman terlambat datang kepadanya.

\section{b. Tipecholeris}

Tipe choleris disebut juga dengan tipe pemberani. Menurut Heymans dalam Suryabrata (2011: 70), tipe ini memiliki kriteria sifat salah satunya adalah bijaksana. Dalam analisis novel Negeri 5 Menara karya Ahmad Fuadi, Alif (tokoh utama) memiliki 1 kepribadian yaitu pemberani dengan sifat bijaksana.

1. Pemberani

Menurut teori kepribadian Heymans kepribadian "pemberani” masuk ke dalam kualitas kejiwaan proses pengiring. Proses pengiring merupakan banyak sedikitnya pengaruh kesankesan terhadap kesadaran. Kepribadian pemberani berarti kepribadian yang sifatnya bijaksana. Oleh karena itu, kepribadian ini termasuk tipe kepribadian choleris. Dalam novel ini, kepribadian Alif yang pemberani adalah seperti pada kutipan berikut.

"Aku mengangkat muka, walau jeri, aku coba pandang mukanya, harus sampai bagian jenggot. Matanya terlalu tajam. Dengan susah payah aku coba kembali susun kalimat di kepala. "Ustad, saya mau beli qalam kaligrafi di kota karena di sini tidak ada..."

"Tidak mungkin. Saya juga kaligrafer, semua alat tersedia di sini," katanya memotong cepat.

"Tapi..tapi...qalam yang ada hanya untuk kaligrafi biasa. Saya ingin mencoba kaligrafi khoufi yang penuh garis-garis dan hiasan daun, Tad. Lebih dibutuhkan spidol tebal tipis dan penggaris dibandingkan qalam biasa," belaku" (Fuadi, 2013: 126).

Kutipan di atas menggambarkan kepribadian Alif yang berani meminta izin ke Ponorogo bersama teman-temannya yang sebenarnya hanya untuk refreshing saja. Satu per satu Alif dan teman-temannya menghadap Ustad Torik untuk meminta Izin dengan memberikan alasan masing-masing. Alasan tersebut harus kuat agar dapat dipercaya oleh Ustad Torik dan memberi izin untuk keluar. Tiba giliran Alif yang menghadap Ustad Torik, dengan alasan untuk membeli peralatan kaligrafi khoufi karena di PM tidak ada.

Berdasarkan hasil analisis data di atas maka data kepribadian Alif dapat dideskripsikan dalam table sebagai berikut.

Table.4.1

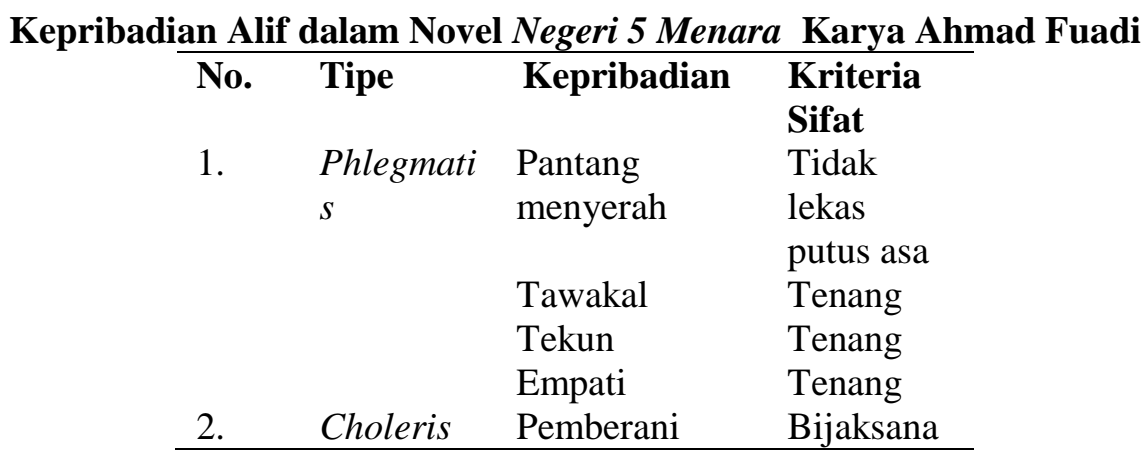

\section{Analisis Kepribadian Alif dalam Novel Ranah 3 Warna Karya Ahmad Fuadi}

Aspek kepribadian tokoh utama dalam novel Ranah 3 Warna karya Ahmad Fuadi kajian psikologi sastra meliputi kepribadian tipe gepasioner (orang hebat) dan phlegmatis (orang tenang). 
Aspek kepribadian Alif tipe gepasioner (memiliki ciri emosional yang kuat, fungsi sekunder, dan aktif), sedangkan aspek kepribadian Alif tipe phlegmatis (memiliki ciri emosional yang lemah, berfungsi sekunder dan aktif) dalam novel ini adalah sebagai berikut.

a. Tipe gepasioner

Tipe gepasioner disebut juga dengan tipe orang hebat. Menurut Heymans dalam Suryabrata (2011: 70), tipe ini memiliki kriteria sifat diantaranya adalah sibuk, kuat menentang penghalang, dan tetap di dalam pendapatnya. Dalam analisis novel Ranah3 Warna karya Ahmad Fuadi, Alif (tokoh utama) memiliki 3 kepribadian yaitu pekerja keras, tangguh, dan percaya diri dengan sifat yang berbeda-beda.

1) Pekerja keras

Menurut teori kepribadian Heymans kepribadian "pekerja keras" masuk ke dalam kualitas kejiwaan aktivitas. Aktivitas merupakan banyak sedikitnya orang menyatakan diri, menjelmakan perasaan-perasaannya, dan pikiran-pikirannya dalam tindakan yang spontan. Kepribadian pekerja keras berarti kepribadian yang sifatnya sibuk. Oleh karena itu, kepribadian ini termasuk tipe kepribadian gepasioner (orang hebat). Dalam novel ini, kepribadian Alif yang pemberani adalah seperti pada kutipan berikut.

"Kamarku kini seperti toko barang bekas. Buku dan catatan usang berceceran di sana-sini. Pelan-pelan, aku tumpuk semua buku di lantai berdasarkan kelas. Hasilnya, satu bukit buku untuk pelajaran kelas satu, satu bukit kelas dua, dan satu bukit kelas tiga. Tiga bukit buku! Aku meneguk ludah. Aku baru sadar ketiga bukit inilah yang akan aku daki kalau ingin menaklukkan ujian persamaan SMA dan UMPTN" (Fuadi, 2013: 9).

Kutipan di atas menggambarkan kepribadian Alif yang sangat pekerja keras, karena ia ingin menaklukkan ujian persamaan dan UMPTN agar bisa mewujudkan citacitanya yaitu kuliah. Begitu banyak buku yang harus ia pelajari dalam waktu dekat, ada 3 bukit buku yaitu 1 bukit untuk kelas 1,1 bukit untuk kelas 2, dan 1 bukit untuk kelas 3. Dengan penuh semangat satu per satu Alif buka buku tersebut dan mulai membaca. Namun, baru baca beberapa lembar saja Alif sudah pusing dengan pelajaran hitungan. Randai yang ia minta untuk mengajarinya hitungan juga ikut pusing karena kurang paham. Akhirnya Alif memutuskan untuk menguburkan impiannya kuliah di ITB dan ia lebih cocok kuliah dengan jurusan IPS.

2) Tangguh

Menurut teori kepribadian Heymans kepribadian "tangguh" masuk ke dalam kualitas kejiwaan aktivitas. Aktivitas merupakan banyak sedikitnya orang menyatakan diri, menjelmakan perasaan-perasaannya, dan pikiran-pikirannya dalam tindakan yang spontan. Kepribadian tangguh berarti kepribadian yang sifatnya kuat menentang penghalang. Oleh karena itu, kepribadian ini termasuk tipe kepribadian gepasioner (orang hebat). Dalam novel ini, kepribadian Alif yang pemberani adalah seperti pada kutipan berikut.

"Apa gunanya masa muda kalau tidak untuk memperjuangkan cita-cita besar dan membalas budi orang tua? Biarlah tulang mudaku remuk dan badanku susut. Aku ikhlas mengorbankan masa muda yang indah seperti yangdinikmati kawan-kawanku. Karena itu aku tidak boleh lemah. Aku harus keras pada diriku sendiri. Pedih harus aku rasai untuk tahu benar rasanya senang. Harus berjuang melebihi rata-rata orang lain. Man jadda wajada!" (Fuadi, 2013: 117).

Dari kutipan di atas, Alif memiliki kepribadian yang sangat tangguh, karena Alif rela tidak bisa menghabiskan waktu bersama teman-temannya, karena disibukkan dengan berbagai macam kegiatan, seperti berjualan, mengajar, bahkan menulis. Tetapi mengingat kondisi keuangan keluarga terutama ibu dan kedua adiknya yang masih sekolah tentu tidak akan cukup jika hanya mengharapkan dari gaji ibu yang mengajar 
di Madrasah Tsanawiyah (SMP) di kampung. Alif harus bekerja dan bisa mengirimkan uang untuk ibu, dan kedua adiknya. Alif harus memperjuangkan cita-cita dan harus bisa membalas budi orang tua.

3) Percaya diri

Menurut teori kepribadian Heymans kepribadian "percaya diri" masuk ke dalam kualitas kejiwaan aktivitas. Aktivitas merupakan banyak sedikitnya orang menyatakan diri, menjelmakanperasaan-perasaannya, dan pikiran-pikirannya dalam tindakan yang spontan. Kepribadian tangguh berarti kepribadian yang sifatnya tetap di dalam pendapatnya.Oleh karena itu, kepribadian ini termasuk tipe kepribadian gepasioner (orang hebat). Dalam novel ini, kepribadian Alif yang pemberani adalah seperti pada kutipan berikut.

"Siap, Yah. Jadi ambo bertekad akan memaksimalkan usaha persis seperti Denmark. Membalikkan penilaian semua orang yang memandang sebelah mata!" (Fuadi, 2013: 25).

Dari kutipan di atas, jelas bahwa Alif sangat percaya diri akan lulus UMPTN dan bisa masuk universitas negeri di Bandung. Meskipun Alif tidak bisa kuliah di ITB dengan mengambil jurusan Teknik Penerbangan, ia tetap bersyukur masih bisa kuliah meskipun di universitas Padjajaran Bandung jurusan Hubungan Internasional. Alif bahkan menyamakan dirinya dengan Denmark, negara yang pada saat pertandingan sepak bola selalu diremehkan banyak orang. Akan tetapi, Denmark tidak menghiraukan semua itu, saat menit-menit terakhir ia bisa membuktikan kepada semua orang bahwa Denmark bisa dan akhirnya juara piala Eropa. Alif harus seperti Denmark terus berusaha dan buktikan kepada semua orang bahwa ia bisa.

b. Tipe phlegmatis

Tipe phlegmatis disebut juga dengan tipe orang tenang. Menurut Heymans dalam Suryabrata (2011: 70), tipe ini memiliki kriteria sifat diantaranya adalah bijaksana, praktis, suka menolong, dan tidak lekas putus asa. Dalam analisis novel Ranah3 Warna karya Ahmad Fuadi, Alif (tokoh utama) memiliki 4 kepribadian yaitu cerdas, sederhana, peduli, dan pantang menyerah dengan sifat yang berbeda-beda.

1) Cerdas

Menurut teori kepribadian Heymans kepribadian "cerdas" masuk ke dalam kualitas kejiwaan proses pengiring. Proses pengiring merupakan banyak sedikitnya pengaruh kesan-kesan terhadap kesadaran. Kepribadian cerdas berarti kepribadian yang sifatnya bijaksana.Oleh karena itu, kepribadian ini termasuk tipe kepribadian phlegmatis. Dalam novel ini, kepribadian Alif yang cerdas adalah seperti pada kutipan berikut.

"Begitu moderator membuka sesi tanya-jawab, aku mengacungkan tangan tinggi-tinggi, bahkan tidak cukup dengan mengacung, aku sampai berdiri. Melebihkan usaha di atas orang lain, begitu yang aku pelajari di PM dulu. Mungkin bertanya di kala situasi mengantuk adalah caraku untuk bekerja di atas rata-rata teman-teman yang tertidur" (Fuadi, 2013: 48).

Kutipan di atas menggambarkan kepribadian Alif yang sangat cerdas ketika menjadi mahasiswa baru yang pada saat itu sedang ada kegiatan ospek di kampusnya. Alif sangat cerdas dalam memanfaatkan waktu ketika ceramah dari dosen senior yaitu Profesor Dr.Mochtar Kusumaatmadja, mantan luar negeri yang dulu sering di TVRI berlangsung. Setelah lama-kelamaan mendengar ceramah banyak mahasiswa yang mengantuk bahkan sebagian lainnya tidur. Dikesempatan itu Alif sangat cerdas dalam memanfaatkan waktu, yaitu ketika sesi tanya jawab dibuka Alif langsung bertanya kepada narasumber tersebut. Dengan penuh semangat Alif mengacungkan tangan 
tinggi-tinggi bahkan sampai berdiri. Alif tahu cara menghilangkan kantuk dikala temantemannya tertidur.

2) Sederhana

Menurut teori kepribadian Heymans kepribadian "sederhana" masuk ke dalam kualitas kejiwaan emosionalitas. Emosionalitas merupakan mudah atau tidaknya perasaan orang terpengaruh oleh kesan-kesan. Kepribadian sederhana berarti kepribadian yang sifatnya praktis. Oleh karena itu, kepribadian ini termasuk tipe kepribadian phlegmatis. Dalam novel ini, kepribadian Alif yang sederhana adalah seperti pada kutipan berikut.

"Ooh. Dia mengintip wajahku dari balik kacamatanya yang melorot. Mungkin kurang percaya melihat mahasiswa ceking dengan baju lusuh dan berkacamata seperti aku ini" (Fuadi, 2013: 151).

Berdasarkan kutipan di atas jelas bahwa Alif memang sederhana, dan apa adanya. Seperti pada saat pergi ke kantor redaksi harian Manggala untuk mengambil honor pertamanya menulis opini di media lokal. Alif tidak memikirkan bagaimana pandangan orang tentang dirinya, ia tetap berpenampilan sederhana. Bahkan pada saat menemui sekretaris redaksi, Alif kurang dipercaya kalau ia adalah seorang mahasiswa dan menulis opini di media harian Manggala. karena pakaian Alif yang lusuh kurang disetrika.

3) Peduli

Menurut teori kepribadian Heymans kepribadian "peduli" masuk ke dalam kualitas kejiwaan proses pengiring. Proses pengiring merupakan banyak sedikitnya pengaruh kesan-kesan terhadap kesadaran. Kepribadian peduli berarti kepribadian yang sifatnya suka menolong. Oleh karena itu, kepribadian ini termasuk tipe kepribadian phlegmatis. Dalam novel ini, kepribadian Alif yang sederhana adalah seperti pada kutipan berikut.

"Aku prihatin menatap Ayah. Sudah aku perhatikan sejak beberapa minggu ini mukanya semakin tirus dan pucat. Aku bahkan tidak berani meninggalkan Ayah dalam kondisi begini" (Fuadi, 2013: 39).

Kutipan di atas menjelaskan kepribadian Alif yang peduli terhadap kondisi ayahnya yang sedang sakit. Alif yang akan merantau ke Bandung untuk melanjutkan sekolah yaitu kuliah di UNPAD. Alif yang lebih dulu merantau ke Jawa merasa sudah terbiasa merantau jauh dari keluarga. Kali ini juga merantau dengan seorang diri tanpa diantar oleh orang tuanya. Disisi lain Alif sangat peduli kepada keluarganya terutama ayahnya yang pada saat itu sedang sakit, dan sangat berat untuk meninggalkannya. Ayahnya yang biasanya terlihat kuat, dan semangat kini badannya terasa lemah, kepala terasa berat, dan suara melemah. Hal tersebut membuat Alif semakin khawatir untuk merantau jauh meninggalkan ayah yang sedang sakit seperti itu.

4) Pantang menyerah

Menurut teori kepribadian Heymans kepribadian "pantang menyerah" masuk ke dalam kualitas kejiwaan proses pengiring. Proses pengiring merupakan banyak sedikitnya pengaruh kesan-kesan terhadap kesadaran. Kepribadian pantang menyerah berarti kepribadian yang sifatnya tidak lekas putus asa. Oleh karena itu,kepribadian ini termasuk tipe kepribadian phlegmatis. Dalam novel ini, kepribadian Alif yang pantang menyerah adalah seperti pada kutipan berikut.

"Aduh. Baru saja aku senang dengan tulisanku, sudah ada tugas baru. Mulutku mau mengeluh, tapi aku paksakan hatiku untuk menerima tantangan ini. Sudah kepalang tanggung, aku harus hadapi dia. Aku tidak boleh menyerah kalau ingin dapat ilmu" (Fuadi, 20113: 78).

Kutipan di atas menjelaskan bahwa Alif memiliki kepribadian pantang menyerah yaitu ketika mendapat tugas menulis dari Bang Togar. Meskipun baru saja 
menyelesaikan tugas menulis dan baru saja dikumpulkan, tetapi Alif sudah mendapatkan tugas menulis lagi. Alif sempat menyerah untuk tugas selanjutnya. Tetapi Alif sudah membuktikan kepada Bang Togar untuk selalu bisa bekerja cepat dan tepat waktu. Bahkan untuk tugas selanjutnya Alif disuruh menulis dengan tema "Imperialisme di Dunia Modern".

Berdasarkan hasil analisis data di atas maka data kepribadian Alif dapat dideskripsikan dalam table sebagai berikut.

Table.4.2

Kepribadian Alif dalam Novel Ranah 3 Warna Karya Ahmad Fuadi

\begin{tabular}{|c|c|c|c|}
\hline No. & Tipe & Kepribadian & $\begin{array}{l}\text { Kriteria Sifat } \\
\text { Sibuk }\end{array}$ \\
\hline 1. & & $\begin{array}{l}\text { Pekerja keras } \\
\text { Tangguh }\end{array}$ & $\begin{array}{l}\text { Sibuk } \\
\text { Kuat menentang } \\
\text { penghalang }\end{array}$ \\
\hline & & Percaya diri & $\begin{array}{l}\text { Tetap di dalam } \\
\text { pendapatnya }\end{array}$ \\
\hline 2. & Phlegmatis & $\begin{array}{l}\text { Cerdas } \\
\text { Sederhana } \\
\text { Peduli } \\
\text { Pantang menyerah }\end{array}$ & $\begin{array}{l}\text { Bijaksana } \\
\text { praktis } \\
\text { suka menolong } \\
\text { tidak lekas putus asa }\end{array}$ \\
\hline
\end{tabular}

\section{Analisis Kepribadian Alif dalam Novel Rantau 1 Muara Karya Ahmad Fuadi}

Aspek kepribadian tokoh utama dalam novel Rantau 1 Muara karya Ahmad Fuadi kajian psikologi sastra meliputi kepribadian tipe phlegmatis (orang tenang), gepasioner (orang hebat) dan choleris (pemberani). Aspek kepribadian Alif tipe phlegmatis (memiliki ciri emosional yang lemah, berfungsi sekunder dan aktif), tipe gepasioner (memiliki ciri emosional yang kuat, fungsi sekunder, dan aktif), sedangkan tipe choleris (memiliki ciri emosional yang kuat, fungsi primer, dan aktif) dalam novel ini adalah sebagai berikut.

a. Tipe phlegmatis

Tipe phlegmatis disebut juga dengan tipe orang tenang. Menurut Heymans dalam Suryabrata (2011: 70), tipe ini memiliki kriteria sifat diantaranya adalah tenang, suka menolong, dan tidak lekas putus asa.Dalam analisis novel Rantau 1 Muara karya Ahmad Fuadi, Alif (tokoh utama) memiliki 4 kepribadian yaitu tekun, tawakal, cerdas, peduli, dan pantang menyerah dengan sifat yang berbedabeda.

1) Tekun

Menurut teori kepribadian Heymans kepribadian "tekun" masuk ke dalam kualitas kejiwaan proses pengiring. Proses pengiring merupakan banyak sedikitnya pengaruh kesan-kesan terhadap kesadaran. Kepribadian tekun berarti kepribadian yang sifatnya tenang. Oleh karena itu, kepribadian ini termasuk tipe kepribadian phlegmatis. Dalam novel ini, kepribadian Alif yang tekun adalah seperti pada kutipan berikut.

"Aku pun mulai mengantuk dan mataku sepet. Tapi aku paksakan menyelesaikan satu bab latihan TOEFL lagi" (Fuadi, 2013: 153).

Kutipan di atas menggambarkan kepribadian Alif yang semakin tekun dalam belajar. Alif yang sebelumnya mendapat telepon dari Randai yang memberitahukan bahwa tidak lama lagi akan melanjutkan sekolahnya di Jerman. Semenjak itu Alif semakin tekun untuk belajar TOEFL 
agar nilai TOEFL pada saat sekolah nanti bagus. Beberapa hari belakangan Alif selalu mencari S2 yang cocok untuk pengembangan antara ilmu dan karier.

2) Tawakal

Menurut teori kepribadian Heymans kepribadian "tawakal" masuk ke dalam kualitas kejiwaan proses pengiring. Proses pengiring merupakan banyak sedikitnya pengaruh kesan-kesan terhadap kesadaran. Kepribadian tawakal berarti kepribadian yang sifatnya tenang. Oleh karena itu, kepribadian ini termasuk tipe kepribadian phlegmatis. Dalam novel ini, kepribadian Alif yang tawakal adalah seperti pada kutipan berikut.

"Semoga kerja kerasku membaca buku TOEFL dan GRE setiap hari sejak berbulan-bulan lalu akan membuahkan hasil bagus. Aku percaya dengan man yazra' yahsud. Siapa yang menanam, akan menuai" (Fuadi, 2013: 172-173).

Kutipan di atas menggambarkan kepribadian Alif yang selalu tawakal terhadap apa yang sudah dilakukannya. Alif yang sudah dinyatakan lulus sebagai penerima beasiswa Fulbright. Alif tetap terus berusaha dan berjuang untuk memastikan diterima di salah satu universitas Amerika. Dengan begitu nilai TOEFL dan GRE-ku harusmenerima syarat penerimaan. Alif tidak pernah lupa untuk terus berdoa dan tawakal kepada Allah untuk mendapatkan hasil yang memuaskan. Alif berharap dan percaya kepada Allah bahwa kerja kerasnya membaca buku TOEFL dan GRE sejak berbulan-bulan akan membuahkan hasil.

3) Peduli

Menurut teori kepribadian Heymans kepribadian "peduli" masuk ke dalam kualitas kejiwaan proses pengiring. Proses pengiring merupakan banyak sedikitnya pengaruh kesan-kesan terhadap kesadaran. Kepribadian peduli berarti kepribadian yang sifatnya suka menolong. Oleh karena itu, kepribadian ini termasuk tipe kepribadian phlegmatis. Dalam novel ini, kepribadian Alif yang sederhana adalah seperti pada kutipan berikut.

"Adapun Pasus tidak bergerak seperti orang mati, sampai aku gagal membangunkannya. "Ya sudah, kesiangan tanggung sendiri ya Sus," kataku setelah tiga kali menggoyang-goyang bahunya. Dia membalas dengan kecapan mulut dan dengkuran halus" (Fuadi, 2013: 75).

Kutipan di atas menggambarkan kepribadian Alif yang peduli kepada temannya Pasus. Pada suatu hari semua wartawan majalah Derap dikejar deadline sehingga harus menyelesaikan laporan investigasi kekayaan para pejabat Orde Baru. Alif dan teman-temannya memutuskan untuk menginap di kantor dan paginya baru pulang. Setelah azan Subuh berkumandang dari masjid yang berada di belakang kantor, Alif dan teman-teman terlonjak bangun kecuali Pasus. Alif sebagai teman peduli kepada Pasus dan membangunkannya hingga bangun. Akan tetapi Pasus yang tidurnya sudah seperti orang mati, membuat Alif berhenti untuk membangunkannya, karena pagi itu akan ada rapat antara staf personalia dan petinggi Derap. Pasus tidak terlihat dalam rapat itu dan ternyata Pasus masih tidur di bawah meja rapat tersebut.

4) Pantang menyerah

Menurut teori kepribadian Heymans kepribadian "pantang menyerah" masuk ke dalam kualitas kejiwaan proses pengiring. Proses pengiring merupakan banyak sedikitnya kesan-kesan terhadap kesadaran. Kepribadian pantang menyerah berarti kepribadian yang sifatnya tidak lekas putus asa. Oleh karena itu, kepribadian ini termasuk tipe kepribadian phlegmatis. Dalam novel ini, kepribadian Alif yang pantang menyerah adalah seperti pada kutipan berikut.

"Meski begitu, aku tetap tidak mau menyerah dan tidak mau menerima kenyataan dia hilang bagai ditelan Bumi. Aku tetap ingin bertahan di New York. Aku harus menemukan Mas Garuda, hidup atau mati. Ini fokus utamaku" (Fuadi, 2013: 351).

Kutipan di atas menggambarkan kepribadian Alif yang pantang menyerah, yaitu terlihat dari usaha Alif untuk menemukan Mas Garuda. Mas Garuda yang diberitakan terkena musibah, karena tempat kerja Mas Garuda di New York terbakar, bahkan ada pesawat yang menabrak menara berlantai 100 itu. Mendengar banyaknya korban dari musibah tersebut, Alif tidak akan menyerah sebelum mendapatkan data atau informasi tentang korban-korban dalam kecelakaan 
tersebut. Mas Garuda sudah seperti kakak kandung, membuat Alif semakin cemas dan khawatir tentang bagaimana keadaan Mas Garuda.

\section{b. Tipe gepasioner}

Tipe gepasioner disebut juga dengan tipe orang hebat. Menurut Heymans dalam Suryabrata (2011: 70), tipe ini memiliki kriteria sifat salah satunya adalah sibuk. Dalam analisis novel Rantau 1 Muara karya Ahmad Fuadi, Alif (tokoh utama) memiliki 1 kepribadian yaitu pekerja keras dengan sifat sibuk.

1) Pekerja keras

Menurut teori kepribadian Heymans kepribadian "pekerja keras" masuk ke dalam kualitas kejiwaan aktivitas. Aktivitas merupakan banyak sedikitnya orang menyatakan diri, menjelmakan perasaan-perasaannya, dan pikiran-pikirannya dalam tindakan yang spontan. Kepribadian pekerja keras berarti kepribadian yang sifatnya sibuk. Oleh karena itu, kepribadian ini termasuk tipe kepribadian gepasioner (orang hebat). Dalam novel ini, kepribadian Alif yang pemberani adalah seperti pada kutipan berikut.

"Aku kembali duduk di depan komputer, memutar lagi tape recorder, dan meneruskan transkip wawancaraku dengan ahli sejarah politik, Dr. Taslim. Setelah itu aku masih harus membuat profil lima partai baru yang paling berpotensi memenangkan pemilu" (Fuadi, 2013: 97).

Kutipan di atas menggambarkan kepribadian Alif yang sangat pekerja keras. Alif yang pada malam itu sedang mengerjakan tugas yang sangat deadline. Tugasnya adalah menganalisis profil 48 partai yang akan ikut Pemilu 1999. Tentu tugas tersebut membutuhkan energi dan waktu yang panjang. Oleh karena itu, semua redaktur yang sedang bekerja mendapat makan gratis. Alif yang sebelumnya sudah mewawancarai ahli sejarah politik Dr.Taslim, dengan tekun mendengarkan tape recorder yang menyimpan hasil wawancaranya dengan sejarah politik tersebut. Selain itu, Alif juga harus membuat profil lima partai baru yang paling berpotensi memenangkan pemilu.

\section{c. Tipecholeris}

Tipe choleris disebut juga dengan tipe pemberani. Menurut Heymans dalam Suryabrata (2011: 70), tipe ini memiliki kriteria sifatsalah satunya adalah bijaksana.Dalam analisis novel Rantau 1 Muara karya Ahmad Fuadi, Alif (tokoh utama) memiliki 1 kepribadian yaitu pemberani dengan sifat bijaksana.

1) Pemberani

Menurut teori kepribadian Heymans kepribadian "pemberani" masuk ke dalam kualitas kejiwaan proses pengiring. Proses pengiring merupakan banyak sedikitnya pengaruh kesan-kesan terhadap kesadaran. Kepribadian pemberani berarti kepribadian yang sifatnya bijaksana. Oleh karena itu, kepribadian ini termasuk tipe kepribadian choleris. Dalam novel ini, kepribadian Alif yang pemberani adalah seperti pada kutipan berikut.

"Tiada pilihan lain. Bapak malaikat ini tidak bisa diharapkan. Jadinya tinggallah urusan antara aku dan jemaah mayat ini. Di antara zikir, aku bisikkan salam kepada para penduduk kamar ini. "Assalamualaikum". Tidak ada jawaban. Dan aku memang tidak ingin mendengar ada yang menjawab" (Fuadi, 2013: 93).

Kutipan di atas menggambarkan kerpibadian Alif yang sangat pemberani ketika mendapat tugas dari Mas Malaka untuk mewawancarai pocong. Wawancaranya pun baru boleh dilakukan pukul 24.00. Alif diminta untuk mengidentifikasi mayat-mayat yang ada di rumah sakit tersebut. Setelah tiba di rumah sakit Alif langsung menemui satpam rumah sakit dan penjaga kamar mayat untuk meminta izin wawancara mayat-mayat yang ada di kamar mayat tersebut. Ketika sudah di 
ruangan tersebut Alif mulai mengidentifikasi mayat-mayat tersebut. Keberanian Alif harus lebih ditingkatkan agar dapat melaksanakan tugas tersebut dengan baik.

Berdasarkan hasil analisis data di atas maka data kepribadian Alif dapat dideskripsikan dalam table sebagai berikut.

\section{Table.4.3}

Kepribadian Alif dalam Novel Rantau 1 Muara Karya Ahmad Fuadi

\begin{tabular}{llll}
\hline No. & Tipe & Kepribadian & $\begin{array}{l}\text { Kriteria } \\
\text { Sifat }\end{array}$ \\
1. & Phlegmatis & Tekun & Tenang \\
& & Tawakal & Tenang \\
& & Peduli & Suka \\
& & menolong \\
& & Pantang & Tidak lekas \\
& & menyerah & putus asa \\
2. & Gepasioner & Pekerja keras & Sibuk \\
3. & Choleris & Pemberani & Bijaksana \\
\hline
\end{tabular}

\section{Simpulan}

Berdasarkan hasil analisis data kepribadian Alif dalam trilogi novel Negeri 5 Menara, Ranah 3 Warna, Rantau 1 Muara karya Ahmad Fuadi, menghasilkan 18 kepribadian.Dalam novel Negeri 5 Menara terdiri atas 5 kepribadian, di antaranya pantang menyerah, tawakal, pemberani, tekun, dan empati. Kelima kepribadian tersebut termasuk dalam dua tipe kepribadian yaitu phlegmatis (pantang menyerah, tawakal, tekun, empati) sedangkan choleris (pemberani). Kepribadian Alif dalam novel Ranah 3 Warna terdiri atas 7 kepribadian (pekerja keras, tangguh, percaya diri, cerdas, sederhana, peduli, dan pantang menyerah). Ketujuh kepribadian tersebut termasuk dalam dua tipe kepribadian yaitu gepasioner (pekerja keras, tangguh, percaya diri) dan phlegmatis (cerdas, sederhana, peduli, pantang menyerah). Sedangkan kepribadian Alif dalam novel Rantau 1 Muara terdiri atas 6 kepribadian (tekun, tawakal, peduli, pantang menyerah, pekerja keras, dan pemberani).Keenam kepribadian tersebut termasuk dalam tiga tipe kepribadian yaitu phlegmatis (tekun, tawakal, peduli, pantang menyerah), gepasioner (pekerja keras), dan choleris (pemberani).

Jadi, dapat disimpulkan bahwa kepribadian pantang menyerah lebih mendominasi karena kepribadian tersebut terdapat dalam trilogi novel. Hal tersebut menandakan bahwa Alif memiliki kepribadian yang pantang menyerah dalam menuntut ilmu khususnya menggapai impian. Jangan pernah menyerah sebelum impian tersebut terwujud.

\section{Ucapan Terima Kasih}

Terima kasih kepada semua pihak yang membantu penulis dalam menyelesaikan artikel hasil riset ini sehingga bisa diterbitkan di Jurnal Hortatori.

\section{Daftar Rujukan}

Djaali. 2009. Psikologi Pendidikan. Jakarta: Bumi Aksara.

Fuad, Anis dan Nugroho, Kandung Sapto. 2014. Panduan Praktis Penelitian Kualitatif. Yogyakarta: Graha Ilmu.

Fuadi, Ahmad. 2012. Negeri 5 Menara. Jakarta: PT Gramedia Pustaka Utama.

Fuadi, Ahmad . 2013. Ranah 3 Warna. Jakarta: PT Gramedia Pustaka Utama.

Fuadi, Ahmad .2013. Rantau 1 Muara. Jakarta: PT Gramedia Pustaka Utama. 
120 The main character's personality in the trilogy novel of Negeri 5 Menara, Ranah 3 Warna, dan Rantau 1 Muara written by Ahmad Fuadi: literature study of SMA

Ibrahim. 2015. Metodologi Penelitian Kualitatif. Bandung: Alfabeta.

Nurgiyantoro, Burhan. 2013. Teori Pengkajian Fiksi. Yogyakarta: Gajah Mada University Press.

Purba, Antilan. 2010. Sastra Indonesia Kontemporer. Yogyakarta: Graha Ilmu.

Ratna, Nyoman Kutha. 2015. Teori, Metode, dan Teknik Penelitian Sastra. Yogyakarta: Pustaka Pelajar.

Rokhmansyah, Alfian. 2014. Studi dan Pengkajian Sastra Perkenalan Awal Terhadap IImu Sastra. Yogyakarta: Graha Ilmu. 